\title{
THE EFFECT OF LEVERAGE, INSTITUTIONAL OWNERSHIP, AND BUSINESS STRATEGY ON TAX AVOIDANCE (CASE OF LISTED MANUFACTURING COMPANIES IN THE CONSUMPTION GOODS INDUSTRY PERIOD 2014-2019)
}

\author{
Vina Novia Damayanti ${ }^{1}$, Sartika Wulandari ${ }^{2}$ \\ ${ }^{1,2}$ Accounting Program, Faculty of Economics and Business, Stikubank University, Jl. Sri Rejeki Utara, \\ Semarang, 50149, Indonesia \\ E-mail: novia221153@gmail.com
}

\begin{abstract}
This study aims to obtain empirical evidence regarding the influence of leverage, institutional ownership, and business strategy on tax avoidance of consumer goods industrial sector manufacturing companies listed in Indonesia Stock Exchange (IDX) under period 2014-2019. The results show that leverage and goods production and distribution have a significant positive effect on tax avoidance while institutional ownership and firm growth have a negative significant effect on tax avoidance. The findings imply that in the context of agency theory, firms shall use debts for tax avoidance in term to reduce the tax but the institutional ownerships tend to control the firm to avoid the tax avoidance.
\end{abstract}

Keywords: leverage; institutional ownership; business strategy; tax avoidance

JEL Classification: G34, H26, K34

\section{Article info:}

Received 3 May 2021

Revised 4 May 2021

Accepted 4 May 2021

Available online 4 May 2021

\section{INTRODUCTION}

The Minister of Finance of the Republic of Indonesia Sri Mulyani revealed that Indonesia's tax revenue in 2019 reached IDR 1,957.2 trillion (including tax revenue of IDR 1,545.3 trillion, non-tax state revenue of IDR 405 trillion, and grants of IDR 6.8 trillion) where this result has grown by $0.7 \%$ compared to the achievements in 2018 so, tax as a fiscal instrument, it is expected to be able to boost national economic competitiveness through the provision of incentives and policies for accelerating restitution in the business world (https://www.kemenkeu.go.id/publikasi/berita/ini-realisasi-penerimaan-negara-dipenghujung-2019/).

Taxes are compulsory contributions to the state that are owed by private persons or entities that are compelling based on law, without receiving direct compensation and used for the state's needs for the greatest prosperity of the people (Law of the Republic of Indonesia Number 6 of 1983 article 1 paragraph 1, https://kemenkeu.go.id/sites/default/files/uukup\%20mobile.pdf). This definition implies that taxes are mandatory levies for the people for the state and are the largest source of revenue for the state.

However, the implementation of tax collection often faces obstacles, especially tax resistance which tends to occur if there is an opportunity from a tax regulatory loophole (Ngadiman \& Puspitasari, 2014). According to Supramono and Damayanti (2010:5), tax resistance can be in the form of passive or active where passive resistance is resistance in the form of obstacles that complicate tax collection and has a close relationship with the economic structure while active resistance is resistance that can be seen clearly in the form of actions. directly shown to the tax authorities with the aim of reducing taxes. 
Deák (2004) and McLaren (2008) explain that for the purpose of reducing tax obligations, taxpayers tend to avoid tax by reducing or eliminating tax burdens by illegal means (tax evasion) or reducing or eliminating tax burdens in a legal way through loopholes that contained in tax regulations (tax avoidance). Consistent with Deák (2004) and McLaren (2008), Gunn et al. (2020) revealed that one form of tax avoidance from taxpayers is implementing tax management strategies or often called tax planning.

Empirical evidence shows that companies tend to use accounting policies to avoid tax (Darmawan \& Sukartha, 2014; Ferdiawan \& Firmansyah, 2017; Karinda, 2018) or other ways that are not in accordance with applicable regulations (Palowa et al., 2018). This evidence implies that there are differences in interests between companies and tax authorities where companies tend to avoid taxes in order to minimize tax burdens. This difference in interests has an impact on the development of tax regulations so that taxpayers carry out tax obligations in accordance with applicable regulations because the government expects optimal tax revenue (Alfaruqi et al., 2019). Empirically, there are several factors that influence a company in implementing tax avoidance, namely leverage (Marfu'ah, 2015; Waluyo et al., 2015; Pajriyansyah \& Firmansyah, 2017; Rahmadani et al., 2020), institutional ownership (Feranika et al., 2016; Wijayani, 2016; Krisna, 2019), and business strategy (Higgins et al., 2015; Purba et al., 2020).

\section{LITERATURE REVIEW}

\section{Agency theory}

Jensen and Meckling (1976) state that agency theory is a theory to explain the conflict in the relationship between the party giving the authority (the principal) and the party receiving the authority (the agent). Jensen and Meckling (1976) explain that the problem that tends to occur between principals and agents is the possibility of managers acting inconsistent with the wishes or interests of the principal. Consistently, Shapiro (2005) explains that management does not always act in accordance with the interests of shareholders because management must have its own interests. This study takes the point of view that tax avoidance practices can be viewed from agency theory in the assumption that the conflict of interest between the agent and the principal in maintaining the desired level of prosperity results in tax avoidance.

\section{Tax avoidance}

Consistent with Deák (2004) and McLaren (2008), Dyreng et al. (2008) prove that tax avoidance is all forms of legal activity from the point of view of taxation regulations that have an effect on tax obligations with the aim of reducing the tax burden. This implies that tax avoidance is carried out by exploiting the weaknesses of tax law so that it does not violate tax law. Shafer and Simmons (2006) explain that tax avoidance is a transaction scheme that aims to minimize the tax burden by taking advantage of loopholes of a country's taxation provisions legally so that it does not violate tax regulations. Marfu'ah (2015), Waluyo et al. (2015), Feranika et al. (2016), Wijayani (2016), Jusman and Nosita (2020), Purba et al. (2020), and Rahmadani et al. (2020) measure tax avoidance by using Cash Effective Tax Rates (CETR).

\section{Hypothesis development}

\section{Leverage and tax avoidance}

Brigham and Ehrhardt (2017:111) suggest that one of the measures of leverage is the ratio of debt to equity or the ratio of debt to assets owned. Brigham and Ehrhardt (2017:109) explain that if assets financed from debt provide profit before tax is lower than debt interest costs, this will not provide benefits for shareholders. This implies that debt can absorb profit which 
can result in reduced tax payments and vice versa if the company does not have debt, taxable profit will be the same as operating profit because there are no debt interest payments. According to Yulfaida and Zulaikha (2012), companies that have a high level of leverage depend on external loans to finance their assets, while companies that have a low level of leverage mostly finance their assets with their own capital. The results of research by Marfu'ah (2015), Waluyo et al. (2015), Pajriyansyah and Firmansyah (2017), and Rahmadani et al. (2020) prove that leverage has a significant positive effect on tax avoidance. Based on this evidence, the research hypothesis is presented below.

H1: Leverage has a significant effect on tax avoidance

\section{Institutional ownership and tax avoidance}

Institutional ownership plays an important role in overseeing the performance of company management to make it more optimal (Sintyawati \& Dewi, 2018). Institutional ownership is shareholders in the form of other institutions or institutions such as insurance companies, banks, investment companies, or other public companies (Prayoga \& Almilia, 2013). Desai and Dharmapala (2009) prove that a large percentage of institutional ownership will have a big impact on monitoring company activities in achieving large profits so that companies tend to avoid tax. However, Tehranian et al. (2006) find that supervisory actions carried out by a firm and institutional investors can limit manager behavior. Shleifer (2009) also proves that institutional ownership plays an important role in monitoring, disciplining, and influencing managers so that it can force managers to minimize tax avoidance. Consistently, Feranika et al. (2016), Wijayani (2016), and Krisna (2019) prove that the greater the institutional ownership, the more likely it is to minimize tax avoidance. Abdillah et al. (2016) prove that the existence of institutional ownership will professionally monitor the development of its investment resulting in a high level of control over management actions so that the potential for fraud can be suppressed. Based on this evidence, the research hypothesis is presented below.

\section{H2: Institutional ownership has a significant effect on tax avoidance}

\section{Business strategy and tax avoidance}

Dess et al. (2021: 6) explain that strategy is a series of ideas, decisions, and actions that make a company successful. Dess et al. (2021: 6) explain that the formulation of strategy is related to the analysis of strategic objectives (vision, mission, and strategic objectives) and analysis of the company's environment (internal and external). Wheelen et al. (2015: 38) state that there are three types of strategies, namely coporate strategy, business strategy, and functional strategy. Wheelen et al. (2015: 38) explain that business strategy emphasizes improving the competitive position of the company's products or services in a specific industry or market segment. Wheelen et al. (2015: 132) argue that there are several types of strategies where the two main types are defenders and prospectors. Regarding tax avoidance, Higgins et al. (2015) prove that defenders tend to do tax avoidance because this type of company emphasizes cost efficiency as a basis for competitive advantage, while prospectors companies are more focused on innovation and growth. Wardani and Khoiriyah (2018) show that there are several factors in business strategy, including: (1) company growth; (2) marketing costs; (3) ability to produce and distribute goods and services; and (4) fixed asset intensity. Akbar et al. (2020) find that company growth has a significant negative impact on tax avoidance even though company growth has different indicators. In addition, even though it has an insignificant impact, Utami and Setyawan (2015), and Jingga and Lina (2017) provide empirical evidence that companies with high growth rates tend to reduce tax avoidance practices. Empirical evidence from Fatmawati and Solikin (2017) also show that companies with relatively large marketing costs will take tax avoidance, even though 
Fathorrahman and Syaiful (2019) show inconsistencies in this evidence. The ability to produce and distribute efficient goods and services is another dimension of business strategy, where companies with high flexibility in production and distribution technology tend to have high income due to the expanding market share so they tend to take tax avoidance (Muhammad, 2012; Harianto, 2020). Empirical evidence from Purwanti and Sugiyarti (2017), and Nasution and Mulyani (2020) also show that companies with high fixed asset intensity tend to do less tax avoidance. Based on this evidence, the research hypothesis is presented below.

H3: Business strategy has a significant positive effect on tax avoidance

\section{RESEARCH METHOD}

\subsection{Sample}

The type of data used in this research is quantitative data which is the annual financial statements of manufacturing companies, especially the consumer goods industry sector for the 2014-2019 period obtained from the official website of the Indonesia Stock Exchange (www.idx.com). A manufacturing company is a type of business that carries out activities as a whole starting from purchasing raw materials, processing raw materials into finished goods and semi-finished goods to the reselling process so that in all activities most of them are related to aspects of taxation. This study determines the sample using a non-probability purposive method, namely the method of determining the sample with certain considerations where the sample members will be selected in such a way that the sample formed can represent the characteristics of the population (Sugiyono, 2007:122). Table 1 shows the sample criteria for this study where based on the criteria, 21 companies in the consumer goods industry sector are listed on the Indonesia Stock Exchange.

Table 1. Sample criteria

\begin{tabular}{lcc}
\hline \multicolumn{1}{c}{ Criteria } & Number of firms & Number of data \\
\hline Listed firms & 43 & 258 \\
Not publicly published financial statements for 2014-2019 & -9 & -54 \\
Not publicly published annual report for 2014-2019 & -5 & -30 \\
Presents the reports in IDR & 0 & 0 \\
Experienced losses in 2014-2019 & -8 & -48 \\
Selected sample & 21 & 126 \\
Data outliers & & -12 \\
Observation data & & 114 \\
\hline
\end{tabular}

\subsection{Dependent variable and independent variable}

The dependent variable in this study is tax avoidance, which is legal action from both legal and moral aspects related to saving tax payments, in other words, tax avoidance is an action taken by taxpayers in an effort to efficiency the tax burden but is still within the limits of the corridor of the law. This study follows Marfu'ah (2015), Waluyo et al. (2015), Feranika et al. (2016), Wijayani (2016), Jusman and Nosita (2020), Purba et al. (2020), and Rahmadani et al. (2020) which measures tax avoidance with Cash Effective Tax Rates (CETR). Dyreng et al. (2008) show that a CETR that is close to or above $20 \%$ indicates that tax avoidance is getting lower. CETR can be calculated as the ratio of the amount of tax payments to profit before tax. The independent variables in this study can be described as follows.

1. Leverage or ratio used to measure the company's short-term and long-term debt ability to finance its assets. This study follows Ngadiman and Puspitasari (2014), and Rahmadani et al. (2020) to measure leverage using the ratio of total debt to total capital or total debt to equity ratio (DER). 
2. Institutional ownership or share ownership of a company which is majority owned by an institution or institution. This study follows Feranika et al. (2016), Wijayani (2016), and Krisna (2019) in measuring institutional ownership which is calculated by the ratio of the number of institutional shares to the number of shares outstanding.

3. Business strategies or strategies that focus on improving competitive advantage in market segments. This study uses several factors as indicators of business strategy, namely:

- Company growth rate. This study follows Muhammad (2012) to measure the company's growth rate which is calculated by the ratio of stock market prices to total capital.

- Marketing. This research follows Muhammad (2012), Fatmawati and Solikin (2017) and Fathorrahman and Syaiful (2019) in measuring marketing indicators through the ratio of advertising costs to total sales.

- The ability to produce and distribute goods and services efficiently. This study follows Muhammad (2012) and Harianto (2020) to measure the ability to produce and distribute goods and services through the ratio of the number of employees to total sales.

- The intensity of fixed assets. This research follows Muhammad (2012), Purwanti and Sugiyarti (2017), and Nasution and Mulyani (2020) in measuring the intensity of fixed assets through the ratio of total fixed assets (property, plant, equipment) to total assets.

\subsection{Method of analysis}

This study uses descriptive statistical analysis to provide an overview or description of data seen from the mean, standard deviation, variance, maximum, minimum, sum, range, kurtosis, and skewness. In addition, this study uses a classic assumption test so that regression can obtain an estimated value that is Best Linear Unisex Estimator (BLUE), which consists of a normality test, multicollinearity test, heteroscedasticity test, and autocorrelation test.

1. Normality test. According to Ghozali (2005:110), the normality test is carried out to determine whether or not there is a normal or abnormal data distribution. According to Ghozali (2005:110), the normality test is tested using the Kolmogorov-Smirnov test where if the significance is more than 0.05 , it can be said that the residual error of the data has been normally distributed. Conversely, if the data residual error is not normally distributed, it can eliminate extreme data (outliers).

2. Multicollinearity test. According to Ghozali (2005:91), multicollinearity occurs when there is a relationship between independent variables. According to Ghozali (2005:91), the multicollinearity test between independent variables is carried out by calculating the tolerance value and Variance Inflation Factor (VIF) where if the tolerance value is more than 0.10 and the VIF is less than 10 then there is no multicollinearity problem in the data.

3. Heteroscedasticity test. According to Ghozali (2005:105), heteroscedasticity means that the residual variance in the model is not the same and results in the estimator having no minimum or inefficient variance. According to Ghozali (2005:105), one way to detect heteroscedasticity symptoms is to perform the Glejser test or regress the independent variable to the absolute residual error (Abs_RES) with the regression equation formula: $|\mathrm{Ut}|=\mathrm{a}+\mathrm{BXt}+\mathrm{vt}$ where if the significance is above 0,05 then there is no symptom of heteroscedasticity in the regression model.

4. Autocorrelation test. According to Ghozali (2005:95), the autocorrelation test is a test carried out to see whether or not there is a relationship or correlation that occurs between samples that are sorted based on the time of deviation that arises in observations or 
observations using time series data. According to Ghozali (2005: 95), autocoreation problems can be detected by using the Durbin-Watson test (DW-Test) where the provisions are if the DW value is more than DU and less than 4-DU (DU <DW <4-DU) then The regression model can be said to be free from autocorrelation problems.

According to Ghozali (2005:82), the coefficient of determination $\left(\mathrm{R}^{2}\right)$ measures how far the model's ability to explain variations in the dependent variable, where if the adjusted $\mathrm{R}^{2}$ value is close to 1 (one) then this means that the independent variable provides almost all the information needed to explain. variation of the dependent variable. This study uses multiple regression tests to test the hypothesis at a significance level of 5\% with equation (1) where $\mathrm{Y}$ is tax avoidance, $\mathrm{X} 1$ is leverage, $\mathrm{X} 2$ is institutional ownership, $\mathrm{X} 3$ is company growth, $\mathrm{X} 4$ is marketing, $\mathrm{X} 5$ is fixed asset intensity, and $\mathrm{X} 6$ is the production and distribution of goods.

$\mathrm{Y}=\alpha+\beta_{1} \cdot \mathrm{X} 1+\beta_{2} \cdot \mathrm{X} 2+\beta_{3} \cdot \mathrm{X} 3+\beta_{4} \cdot \mathrm{X} 3+\beta_{5} \cdot \mathrm{X} 5+\beta_{6} \cdot \mathrm{X} 6+\varepsilon$

\section{RESULTS AND DISCUSSIONS}

\subsection{Results}

Descriptive statistics. Table 2 presents the sample data for this study regarding the mean, minimum, maximum, and standard deviation values for each variable.

Table 2. Descriptive statistics

\begin{tabular}{lccccc}
\hline & N & Minimum & Maximum & Mean & Std. Deviation \\
\hline Leverage & 126 & 0.17 & 3.03 & 0.8261 & 0.61757 \\
Institutional Ownership & 126 & 0.50 & 3.93 & 0.7978 & 0.31224 \\
Company Growth & 126 & 0.00 & 0.02 & 0.0014 & 0.00359 \\
Marketing & 126 & 0.00 & 0.28 & 0.0818 & 0.06695 \\
Fixed Asset Intensity & 126 & 0.06 & 1.31 & 0.4021 & 0.21656 \\
Production and Distribution of Goods & 126 & 0.00 & 0.00 & 0.0003 & 0.00047 \\
Tax Avoidance & 126 & 0.00 & 0.75 & 0.2738 & 0.09853 \\
\hline
\end{tabular}

Classic assumption test. Table 3 shows that the Kolmogorov-Smirnov test probability has a value of 1.315 at a significance of 0.063 or greater than 0.05 so that the data residual error is normally distributed. The variables of leverage, institutional ownership, and business strategy (company growth, marketing, fixed asset intensity, and the ability to produce and distribute goods and services) have a tolerance value of more than 0.10 and a VIF of less than 10 so that these variables free from multicollinearity problems. Based on the Glejser test, the regression results of the independent variables have a significance above 0.05 so that there is no heteroscedasticity problem in the regression model. This study finds that the DurbinWatson value was 1,947 where if the sample used was $114(\mathrm{n}=114)$ with $6(\mathrm{k}=6)$ independent variables at the 0.05 significance level, the DU value in the Durbin-Watson table is obtained 1.8065 and the value of $4-\mathrm{Du}$ is 2.1935 so that DU <DW <(4-DU) or 1.8065 $<1.947<2.1935$ or in the sense that the research data does not occur autocorrelation.

Multiple regression test. Table 3 shows that the leverage variable and the variable production and distribution of goods have a positive and significant coefficient at 5\%, while the institutional ownership variable and the company growth variable have a negative and significant coefficient at 5\%. The result of the $\mathrm{F}$ statistical test has a calculated value of 12,327 and is significant at $5 \%$ so that the regression model is fit and it can be said that the independent variables simultaneously affect the dependent variable. In addition, this study finds that the value of Adjusted R Square is 0.376 or $37.6 \%$ of the dependent variable, namely tax avoidance, can be explained by independent variables, namely leverage, institutional ownership, and business strategy, while $62.4 \%$ is influenced by other factors. not included in this research model. 
Table 3. Multiple regression test

\begin{tabular}{lcccc}
\hline \multirow{2}{*}{ Model } & \multicolumn{2}{c}{$\begin{array}{c}\text { Dependent } \\
\text { Variable }\end{array}$} & \multicolumn{2}{c}{$\begin{array}{c}\text { Collinearity } \\
\text { Statistics }\end{array}$} \\
\cline { 2 - 5 } & Tax Avoidance & RES2 & Tolerance & VIF \\
\hline Constant & 0.312 & 0.025 & & \\
Leverage & $0.021^{*}$ & -0.008 & 0.466 & 2.146 \\
Institutional Ownership & $-0.083^{*}$ & -0.012 & 0.947 & 1.057 \\
Company Growth & $-4.156^{*}$ & 1.678 & 0.597 & 1.676 \\
Marketing & 0.050 & 0.011 & 0.860 & 1.163 \\
Fixed Asset Intensity & -0.017 & 0.031 & 0.679 & 1.473 \\
Production and Distribution of Goods & $17.037^{*}$ & 0.389 & 0.892 & 1.121 \\
\hline F-test & $12.327^{*}$ & & & \\
R & 0.639 & & & \\
R Square & 0.409 & & & \\
Adjusted R Square & 0.376 & & & \\
Std. Error of the Estimate & 0.03947 & & & \\
Kolmogorov-Smirnov Z & 1.315 & & & \\
Durbin-Watson & 1.947 & & & \\
*significant at 5\% & & & &
\end{tabular}

\subsection{Discussions}

Leverage and tax avoidance. The analysis result shows that leverage has a significance level below $5 \%$ so that $\mathrm{H} 1$ is accepted. These results indicate that the greater the use of debt, the higher the company's tax avoidance. The result supports Marfu'ah (2015), Waluyo et al. (2015), Pajriyansyah and Firmansyah (2017), and Rahmadani et al. (2020). Leverage is the company's ability to pay all of its obligations, both short-term and long-term obligations. The higher the value of the leverage ratio, the higher the amount of funding from third party debt used by the company and the higher the interest costs arising from this debt which will have the effect of reducing the company's tax burden.

Institutional ownership and tax avoidance. The results of the analysis show that institutional ownership has a significance level below $5 \%$ so that $\mathrm{H} 2$ is accepted. The results of this study are consistent with Feranika et al. (2016), Wijayani (2016), and Krisna (2019). This study proves that the actions taken by institutional shareholders tend to minimize the risk of being detected as tax avoidance which can reduce the company's reputation so that institutional shareholders.

Business strategy and tax avoidance. The result of the analysis shows that the company's growth has a significance level of below 5\%. This study proves that company growth tends to reduce tax avoidance and is consistent with Utami and Setyawan (2015), Jingga and Lina (2017), and Akbar et al. (2020). The result shows that the marketing variable has a significance level of more than 0.05 and is consistent with Fathorrahman and Syaiful (2019) so that this study proves that marketing factors are not the only thing to determine which companies do tax avoidance. This study also proves that the intensity of fixed assets does not significantly affect tax avoidance so that it is inconsistent with Purwanti and Sugiyarti (2017), and Nasution and Mulyani (2020). Furthermore, the result shows that the ability to produce and distribute goods has a positive and significant coefficient on tax avoidance so that it is consistent with the explanations of Muhammad (2012) and Harianto (2020). Overall, the four business strategy factors show that only the ability to produce and distribute goods that have a positive significant result on tax avoidance, so H3 is rejected. This result implies that the average company has not established a consistent pattern of competitive strategies from year to year so that it does not have an impact on tax avoidance. 


\section{CONCLUSION}

This study aims to determine the effect of leverage, institutional ownership and business strategies on tax avoidance by manufacturing companies in the consumer goods industry listed on the Indonesia Stock Exchange (IDX) in 2014-2019. This study proves that tax avoidance tends to be explained by leverage and institutional ownership. In point of view of agency theory, companies will tend to take legal tax avoidance in order to minimize the tax burden, especially by utilizing debt. Conversely, institutional ownership is a controlling function of the company where the existence of institutional shareholders can control tax avoidance from the company. The results of this study contribute to the development of accounting science, especially in the field of taxation which can provide views on tax avoidance carried out by companies. This research is limited to manufacturing companies in the consumer goods industry which are listed in the IDX on period of 2014-2019. Future studies are expected to use measurements other than CETR with a longer observation period.

\section{REFERENCES}

Abdillah, S. Y., Susilawati, R. A. E., \& Purwanto, N. (2016). Pengaruh good corporate governance pada manajemen laba (Studi empiris pada perusahaan manufaktur yang terdaftar di Bursa Efek Indonesia tahun 2013-2014). Jurnal Riset Mahasiswa Akuntansi, 4(1), 1-14. http://ejournal.unikama.ac.id/index.php/jrma/article/view/1299

Akbar, Z., Irawati, W., Wulandari, R., \& Barli, H. (2020). Analysis of profitability, leverage, sales growth and family ownership on tax avoidation. Jurnal Akuntansi: Kajian Ilmiah Akuntansi, $\quad 7(2), \quad$ 190-199. jurnal.lppmunsera.org/index.php/Akuntansi/article/view/2307

Alfaruqi, H. A., Sugiharti, D. K., \& Cahyadini, A. (2019). Peran pemerintah dalam mencegah tindakan penghindaran pajak sebagai aktualisasi penyelenggaraan pemerintahan yang baik dalam bidang perpajakan. Acta Diurnal: Jurnal Ilmu Hukum Kenotariatan, 3(1), 113-133. https://jurnal.fh.unpad.ac.id/index.php/acta/article/view/216

Brigham, E. F., \& Ehrhardt, M. C. (2017). Financial management: Theory and practice, 15th Edition. United States: Cengage Learning.

Darmawan, I. G. H., \& Sukartha, I. M. (2014). Pengaruh penerapan corporate governance, leverage, roa, dan ukuran perusahaan pada penghindaran pajak. E-Jurnal Akuntansi, 9(1), 143-161. https://ojs.unud.ac.id/index.php/Akuntansi/article/view/8635

Deák, D. (2004). Legal considerations of tax evasion and tax avoidance. Society and Economy, 26(1), 41-85. https://doi.org/10.1556/socec.26.2004.1.2

Desai, M. A., \& Dharmapala, D. (2009). Corporate tax avoidance and firm value. The Review of Economics and Statistics, 91(3), 537-546. https://doi.org/10.1162/rest.91.3.537

Dess, G. G., McNamara, G., Eisner, A. B., Lee, S., \& Sauerwald, S. (2021). Strategic management: Text and cases, $10^{\text {th }}$ Edition. United States: McGraw-Hill Education.

Dyreng, S. D., Hanlon, M., \& Maydew, E. L. (2008). Long-run corporate tax avoidance. The Accounting Review, 83(1), 61-82. https://doi.org/10.2308/accr.2008.83.1.61

Fathorrahman, \& Syaiful. (2019). Pengaruh strategi bisnis perusahaan terhadap penghindaran pajak pada perusahaan manufaktur makanan dan minuman di Bursa Efek Indonesia. J-MACC: Journal of Management and Accounting, 2(1), 1-15. http://ejurnal.unisda.ac.id/index.php/J-MACC/article/view/1440

Fatmawati, O. R., \& Solikin, A. (2017). Pengaruh karakteristik perusahaan dan beban iklan terhadap tindakan penghindaran pajak pada perusahaan manufaktur. Substansi, 1(1), 123-141. http://jurnal.pknstan.ac.id/index.php/SUBS/article/view/212 
Feranika, A., Mukhzarudfa, \& Aurora, T. (2016). Pengaruh kepemilikan institusional, dewan komisaris independen, kualitas audit, komite audit, karakter eksekutif, dan leverage terhadap tax avoidance (Studi empiris pada perusahaan manufaktur di Bursa Efek Indonesia dengan tahun pengamatan 2010-2014). Jurnal Akuntansi \& Keuangan Unja, 1(4), 31-39. https://online-journal.unja.ac.id/jaku/article/view/3180

Ferdiawan, Y.,\& Firmansyah, A. (2017). Pengaruh political connection, foreign activity, dan, real earnings management terhadap tax avoidance. Jurnal Riset Akuntansi dan Keuangan, $5(3)$

$1601-$ 1624.https://ejournal.upi.edu/index.php/JRAK/article/view/9223

Ghozali, I. (2005). Analisis multivariate dengan program SPSS. Semarang: Badan Penerbit Universitas Diponegoro.

Gunn, A. F., Koch, D., \& Weyzig, F. (2020). A methodology to measure the quality of tax avoidance case studies: Findings from the Netherlands. Journal of International Accounting, Auditing and Taxation, 39, 1-18. https://doi.org/10.1016/j.intaccaudtax.2020.100318

Harianto, R. (2020). Pengaruh strategi bisnis, kepemilikan institusional dan kebijakan utang terhadap penghindaran pajak (Studi kasus pada perusahaan makanan dan minuman di Bursa Efek Indonesia tahun 2016-2018). Liability, 2(1), 49-69. https://journal.uwks.ac.id/index.php/liability/article/view/878

Higgins, D., Omer, T. C., \& Phillips, J. D. (2015). The influence of a firm's business strategy on its tax aggressiveness. Contemporary Accounting Research, 32(2), 674-702. https://doi.org/10.1111/1911-3846.12087

Jensen, M. C., \& Meckling, W. H. (1976). Theory of the firm: Managerial behavior, agency costs and ownership structure. Journal of Financial Economics, 3(4), 305-360. https://doi.org/10.1016/0304-405X(76)90026-X

Jingga, V., \& Lina. (2017) Factors influencing tax avoidance activity: An empirical study from Indonesia Stock Exchange. Indian-Pacific Journal of Accounting and Finance, 1(1), 17-25. http://repo.uum.edu.my/id/eprint/26134

Jusman, J., \& Nosita, F. (2020). Pengaruh corporate governance, capital intensity dan profitabilitas terhadap tax avoidance pada sektor pertambangan. Jurnal Ilmiah Universitas Batanghari Jambi, 20(2), 697-704. http://dx.doi.org/10.33087/jiubj.v20i2.997

Karinda, W. (2018). Pengaruh penghindaran pajak yang dimoderasi corporate governance terhadap manajemen laba (Studi empiris pada perusahaan manufaktur yang terdaftar di Bursa Efek Indonesia pada tahun 2014-2017). Jurnal Akuntansi, 6(3), 1-15. http://ejournal.unp.ac.id/students/index.php/akt/article/view/3806

Krisna, A. M. (2019). Pengaruh kepemilikan institusional dan kepemilikan manajerial pada tax avoidance dengan kualitas audit sebagai variabel pemoderasi. Wacana Ekonomi: Jurnal Ekonomi, Bisnis dan Ekonomi, 18(2), 82-91. https://www.ejournal.warmadewa.ac.id/index.php/wacana_ekonomi/article/view/1162

Marfu'ah, L. (2015). Pengaruh return on asset, leverage, ukuran perusahaan, kompensasi rugi fiskal dan koneksi politik terhadap tax avoidance. Skripsi. Universitas Muhammadiyah Surakarta. http://eprints.ums.ac.id/37022/

McLaren, J. (2008). The distinction between tax avoidance and tax evasion has become blurred in Australia: why has it happened?. Journal of the Australasian Tax Teachers Association, https://static1.squarespace.com/static/5e88791f0c333872e0b33272/t/5ee61f83b3fb18 39cc35bbbe/1592139679422/JATTA-2008-Volume3-Issue2-All-Articles.pdf 
Muhammad, B. (2012). Analisis pengaruh strategi perusahaan terhadap tingkat penghindaran pajak pada perusahaan manufaktur yang terdaftar di Bursa Efek Indonesia. Skripsi. Universitas Indonesia. https://library.ui.ac.id/detail.jsp?id=20355088

Nasution, K. M. P., \& Mulyani, S. D. (2020). Pengaruh intensitas aset tetap dan intensitas persediaan terhadap penghindaran pajak dengan pertumbuhan penjualan sebagai variabel moderasi. Prosiding Seminar Nasional Pakar, 2.32.1-2.32.7. https://trijurnal.lemlit.trisakti.ac.id/pakar/article/view/6871/0

Ngadiman, \& Puspitasari, C. (2014). Pengaruh leverage, kepemilikan institusional, dan ukuran perusahaan terhadap penghindaran pajak (tax avoidance) pada perusahaan sektor manufaktur yang terdaftar di Bursa Efek Indonesia 2010-2012. Jurnal Akuntansi, 18(3), 408-421. https://www.neliti.com/id/publications/74028/pengaruhleverage-kepemilikan-institusional-dan-ukuran-perusahaan-terhadap-pengh\#cite

Pajriyansyah, R., \& Firmansyah, A. (2017). Pengaruh leverage, kompensasi rugi fiskal dan manajemen laba terhadap penghindaran pajak. Keberlanjutan: Jurnal Manajemen dan Jurnal Akuntansi, 2(1), 431-459. http://dx.doi.org/10.32493/keberlanjutan.v2i1.y2017.p431-459

Palowa, A., Nangoi, G., \& Gerungai, N. (2018). Analisis faktor - faktor yang mendorong tindakan tax evasion pada wajib pajak UMKM di Kecamatan Madidir Kota Bitung. Going Concern: Jurnal Riset Akuntansi, 13(04), 625-634. https://doi.org/10.32400/gc.13.04.21616.2018

Prayoga, E. B., \& Almilia, L. S. (2013). Pengaruh struktur kepemilikan dan ukuran perusahaan terhadap pengungkapan manajemen risiko. Jurnal Akuntansi dan Keuangan, 4(1), 1-19. http://dx.doi.org/10.36448/jak.v4i1.237

Purba, E. L. D., Yuniar, T. Y., \& Simanullang, R. S. P. (2020). Pengaruh strategi bisnis, karakteristik perusahaan dan tata kelola perusahaan terhadap tax avoidance (Studi empiris pada perusahaan manufaktur yang terdaftar di Bursa Efek Indonesia tahun 2016-2018). Jurnal Akuntansi, Keuangan \& Perpajakan Indonesia, 8(1), 47-56. https://jurnal.unimed.ac.id/2012/index.php/eua/article/view/19026

Purwanti, S. M., \& Sugiyarti, L. (2017). Pengaruh intensitas aset tetap, pertumbuhan penjualan dan koneksi politik terhadap tax avoidance (Studi kasus pada perusahaan manufaktur yang terdaftar di Bursa Efek Indonesia tahun 2012-2016). Jurnal Riset Akuntansi dan Keuangan, 5(3), 1625-1642. https://ejournal.upi.edu/index.php/JRAK/article/view/9225

Rahmadani, Muda, I., \& Abubakar, E. (2020). Pengaruh ukuran perusahaan, profitabilitas, leverage, dan manajemen laba terhadap penghindaran pajak dimoderasi oleh political connection. Jurnal Riset Akuntansi dan Keuangan, 8(2), 375-392. https://ejournal.upi.edu/index.php/JRAK/article/view/22807

Shafer, W., \& Simmons, R. (2008). Social responsibility, machiavellianism and tax avoidance: A Study of Hong Kong tax professionals. Accounting, Auditing \& Accountability Journal, 21(5), 695-720. http://dx.doi.org/10.1108/09513570810872978

Shapiro, S. P. (2005). Agency theory. Annual Review of Sociology, 31(1), 263-284. https://doi.org/10.1146/annurev.soc.31.041304.122159

Shleifer, A. (2009). The age of milton friedman. Journal of Economic Literature, 47(1), 123135. https://doi.org/10.1257/jel.47.1.123

Sintyawati, N., \& Dewi, M. (2018). Pengaruh kepemilikan manajerial, kepemilikan institusional dan leverage terhadap biaya keagenan pada perusahaan manufaktur. $E$ Jurnal Manajemen, 7(2), 933-1020. https://doi.org/10.24843/EJMUNUD.2018.v7.i02.p16

Sugiyono. (2007). Metode penelitian kuantitatif kualitatif dan R\&D. Bandung: Alfabeta. 
Supramono, \& Damayanti, T. (2010). Perpajakan Indonesia: Mekanisme dan perhitungan. Yogyakarta: Andi Offset.

Tehranian, H., Cornett, M. M., Marcus, A. J., \& Saunders, A. (2006). Earnings management, corporate governance, and true financial performance. Working Paper. https://dx.doi.org/10.2139/ssrn.886142

Utami, W. T., \& Setyawan, H. (2015). Pengaruh kepemilikan keluarga terhadap tindakan pajak agresif dengan corporate governance sebagai variabel moderating (Studi empiris pada perusahaan manufaktur yang terdaftar di Bursa Efek Indonesia tahun 2010-2013). Conference In Business, Accounting, and Management, 2(1), 413-421. http://jurnal.unissula.ac.id/index.php/cbam/article/view/324

Waluyo, T. M., Basri, Y. M., \& Rusli. (2015). Pengaruh return on asset, leverage, ukuran perusahaan, kompensasi rugi fiskal dan kepemilikan institusi terhadap penghindaran pajak. Simposium Nasional Akuntansi XVIII. http://lib.ibs.ac.id/materi/Prosiding/SNA\%20XVIII/makalah/160.pdf

Wardani, D. K., \& Khoiriyah, D. (2018). Pengaruh strategi bisnis dan karakteristik perusahaan terhadap penghindaran pajak. Jurnal Akuntansi Dewantara, 2(1), 25-36. https://jurnal.ustjogja.ac.id/index.php/akuntansidewantara/article/view/2181

Wheelen, T. L., Hunger, J. D., Hoffman, A. N., \& Bamford, C. E. (2015). Concepts in strategic management and business policy: Globalization, innovation, and sustainability, $14^{\text {th }}$ Edition, Global Edition. United Kingdom: Pearson Education Limited

Wijayani, D. R. (2016). Pengaruh profitabilitas, kepemilikan keluarga, corporate governance dan kepemilikan institusional terhadap penghindaraan pajak di Indonesia. Jurnal Dinamika Ekonomi \& Bisnis, $\quad 13(2), \quad 181-192$. https://ejournal.unisnu.ac.id/JDEB/article/view/473

Yulfaida, D., \& Zulaikha. (2012). Pengaruh size, profitabilitas, profile, leverage dan ukuran dewan komisaris terhadap pengungkapan tanggung jawab sosial pada perusahaan manufaktur di Bursa Efek Indonesia. Diponegoro Journal of Accounting, 1(1), 214224. https://ejournal3.undip.ac.id/index.php/accounting/article/view/385 